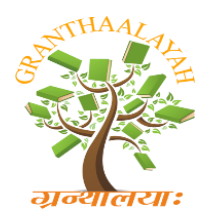

INTERNATIONAL JOURNAL OF RESEARCH GRANTHAALAYAH

A knowledge Repository

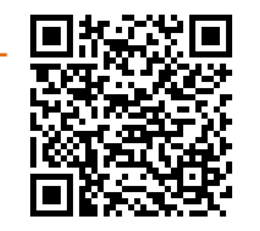

Management

\title{
DOES REALLY ACADEMIC STREAM OF STUDY INFLUENCE POST GRADUATE STUDENTS VALUE PREFERENCE?
}

\author{
R. D. Padmavathy ${ }^{* 1}$ \\ *1 Assistant Professor, Mathematics Education, Department of Education, \\ Tezpur University (A Central University), Assam, INDIA
}

\begin{abstract}
This study examined the effect of academic stream of study of post graduate students on their value dimensions. In the present study survey method was adopted to collect the data among 110 samples using convenient random sampling technique. For collecting the data study of Values Test" developed by Dr. Raj Kumar Ojha, and Dr. Mahesh Bhargava was used. Results indicates that arts and science stream post graduate students differ significantly in their theoretical value, aesthetic value and political value and no difference in economic value, social value and religious values respectively.
\end{abstract}

Keywords:

Post Graduate Students, effect of academic stream, Values Test .

Cite This Article: R. D. Padmavathy, "DOES REALLY ACADEMIC STREAM OF STUDY INFLUENCE POST GRADUATE STUDENTS VALUE PREFERENCE?” International Journal of Research - Granthaalayah, Vol. 4, No. 3: SE (2016): 63-67.

\section{INTRODUCTION}

"We know a person best if we know what kind of future he is bringing about and his molding future rests primarily on his personal values"

- Allport 1961.

Our Indian culture has always preached the good things like simplicity, peace, spirit of service, humanity, and positive actions are good character of human beings. Every human in the world is suffering now because of anti-humans actions committed by another human. As rightly remarked by Albert Einstein "The most important human endeavor is the striving for morality in our actions, our inner balance and even our very existence depend upon it, and only morality in our actions can give beauty and dignity to life". Due to self-centered nature human's big wealth like character, values, virtues, morals and ethics are lost now a day and the barbaric qualities dominating the human life. Scientific and technological revolution changes the human life style but at the same time one things we have to accept our education system produces labours for the market need and failed to give importance to our human values. "Our present educational system 
with all its complexities and intricacies have proved to be deficient so far, as it neglects or does not give deserving importance to values in human life" (Venkataiah,2005). But there is an urgent need to revive reform and nurture the human values life to lead a peaceful society.

\section{DIFFERENT VALUE USED IN THE STUDY}

The current research examines the six personal values preferences described by Allport (1937, 1961) is briefly described below (as cited by Lacey, 1998)

i) Theoretical Value (A) preference leads one to seek to discover truth. Observation, cognitions and reason are essential for bringing order to knowledge.

ii) Economic Value (B) preference is concerned with usefulness and self-preservation. Education is seen as practical, unapplied knowledge is useless. This value is based on the business concepts of acquired wealth, consumption of goods and usefulness of credit. Wealth becomes a means of surpassing others rather than a means to serve or dominate.

iii) Aesthetic value (C) preferences is grounded in the belief that life is series of event each to be enjoyed for its own sake and believe the concepts of harmony and form, see religion in terms of the beauty and pomp of the ceremony rather than traditional worship experience. It runs counter to the interest in welfare of people, repression of individual freedoms and commercialism of business activities.

(iv) Social value $(\mathbf{X})$ preference dominated by an altruistic or philanthropic love of people such as kindness, unselfishness and service of mankind.

(v) Political Value (Y) preference is not necessarily an indication of political power rather it is a leadership trait.

(vi) Religious Value $(\mathbf{Z})$ preference motivates people to search for an understanding how each element fits into the great scheme of things, a search for unity.teh religious value orientation finds divine intervention in every event.

\section{REVIEW OF RELATED LITERATURE}

Reddy and Parameswaran (1966) found engineering, medical and science graduate students were more theoretical and arts subjects students were social, aesthetic value oriented. Pastonjee, Akhtar and Chowdry (1967) found college students gave preference to social service, fame and security. Annamma (1984) found that value differences are noticeable between men and women who are higher educated indicating that men are more materialistic oriented and women are more spiritual oriented. Poduval (1987) identify the dominant values of the MBA students as social, self-esteem, economic and religious. Segal (1993) found there were significant differences in values and personality characteristic of social work students in the U.S and India. Moran, et.al.,(1995) found that MSW students values and aptitudes were more social than those of MBA students. Passakos (1996) found social and religious value has highest stability among teacher training college students. Fatema \& Noor(2012) found that there is no significant difference in theoretical, aesthetic, religious value and significant differences in economic, social and political values between public and private universities male students. The public universities' male students' economic value is higher than that of private universities. 


\section{NEED FOR THE STUDY}

Researches prior to 1985 on values had been limited to religious nature of the beliefs, attitudes and values of teachers in catholic secondary schools (Benson \& Guerra,1985). Very few studies conducted on value orientation of graduate students but understanding the influence of academic stream of study on value preferences of post graduate students is not documented. Hence this study attempted to understand the differences among post graduate students and influence of academic stream of study on their value dimension.

\section{OBJECTIVE}

To study the significant difference among arts and science stream post graduate students on different value dimensions.

\section{HYPOTHESIS}

There exists no significant difference among arts and science stream post graduate students on different value dimensions.

\section{RESEARCH DESIGN}

In the present study survey method was adopted. A sample of 110 students was selected using convenient random sampling technique. In the present research the "Study of Values Test" developed by Dr. Raj Kumar Ojha, and Dr. Mahesh Bhargava is used. In the present study Mean, standard deviation, t-test is used for analysing the data.

\section{DATA ANALYSIS AND INTERPRETATION}

To meet the objective of the study the data was analysed and the results were discussed below

Table 1: Descriptive, 't'- test value for Stream of Study and Value Dimensions of PG Students

\begin{tabular}{|c|c|c|c|c|c|c|c|c|c|}
\hline \multirow{2}{*}{$\begin{array}{l}\text { Value } \\
\text { Dimensions }\end{array}$} & \multirow{2}{*}{$\begin{array}{l}\text { Stream } \\
\text { of study }\end{array}$} & \multirow{2}{*}{$\mathbf{N}$} & \multicolumn{4}{|c|}{ Value Levels } & \multirow[t]{2}{*}{ Mean } & \multirow[t]{2}{*}{ S.D } & \multirow{2}{*}{$\begin{array}{l}\text { ' t '- } \\
\text { Test }\end{array}$} \\
\hline & & & Vh & $\mathrm{Hv}$ & $\mathbf{A v}$ & $\mathbf{P v}$ & & & \\
\hline \multirow[t]{2}{*}{ Theoretical } & Arts & 72 & 8 & 27 & 20 & 17 & 41.9 & 4.80 & \multirow{2}{*}{2.70} \\
\hline & Science & 38 & 7 & 14 & 8 & 9 & 42.1 & 6.72 & \\
\hline \multirow[t]{2}{*}{ Economic } & Arts & 72 & 5 & 15 & 20 & 32 & 41.6 & 6.19 & \multirow{2}{*}{0.27} \\
\hline & Science & 38 & 1 & 10 & 9 & 18 & 41.9 & 5.60 & \\
\hline \multirow[t]{2}{*}{ Aesthetic } & Arts & 72 & 0 & 11 & 33 & 28 & 35.3 & 5.87 & \multirow{2}{*}{2.60} \\
\hline & Science & 38 & 0 & 3 & 21 & 14 & 34.6 & 4.90 & \\
\hline \multirow[t]{2}{*}{ Social } & Arts & 72 & 17 & 36 & 11 & 8 & 45.5 & 6.80 & \multirow{2}{*}{1.02} \\
\hline & Science & 38 & 6 & 20 & 2 & 10 & 43.6 & 5.55 & \\
\hline \multirow[t]{2}{*}{ Political } & Arts & 72 & 3 & 9 & 5 & 55 & 37.4 & 5.06 & \multirow{2}{*}{3.22} \\
\hline & Science & 38 & 0 & 2 & 5 & 31 & 37.6 & 3.63 & \\
\hline \multirow[t]{2}{*}{ Religious } & Arts & 72 & 0 & 16 & 2 & 54 & 34.3 & 7.47 & \multirow{2}{*}{1.58} \\
\hline & Science & 38 & 0 & 6 & 4 & 28 & 34.2 & 5.74 & \\
\hline \multicolumn{7}{|c|}{ Note: Vh- very high, $\mathrm{Hv}$-high, Av- average, $\mathrm{Pv}$ - poor } & \multicolumn{3}{|c|}{$5 \%$ level of significance } \\
\hline
\end{tabular}


From the above table it is found that

- The obtained t-value for arts and science stream students is 2.70 in theoretical values, 2.60 in aesthetic value, 3.22 in political value is greater than the table value 1.96 at 0.05 levels of significance. Hence the null hypothesis is rejected and thus it is concluded that there is a significant mean difference between arts and science stream post graduate students in their theoretical value, aesthetic value and political value respectively.

- The obtained t-value for the arts and science stream students 0.27 in economic value, 1.02 in social value, and 1.58 in religious value are less than the table value 1.96 at 0.05 levels of significance respectively. Hence the null hypothesis is accepted and thus it is concluded that there is no significant mean difference between arts and science stream post graduate students in their economic value, social value and religious values respectively.

\section{CONCLUSION}

Arts and science stream post graduate students differ significantly in their theoretical value, aesthetic value and political value and no difference in economic value, social value and religious values respectively. Understanding the value dimensions and stream of post graduate students will help them as well as society to understand what type of person are living in the society. This study was done with small sample in particular strata of quantitative form. A similar study using qualitative and longitudinal will help to compare the needed, present and expected values from its citizens. This type of study would help the educators, administrators and frame workers to plan according to their student's value levels (who are future parents) and the type of values to be inculcated or enriched/diminished among them through study for the good of society.

\section{REFERENCE}

[1] Annamma, A.K. (1984).Values, Aspirations and Adjustment of College Students in Kerala, Ph.D Thesis, Kerala University.

[2] Fatema-Tu-Zohra Binte Zaman \& Noor Muhammad. (2012).A Comparative Study of the Values of Bangladeshi Male Students in Public and Private Universities. ASA University Review, Vol. 6(1).Pp.33-42.

[3] Lacey, C..H.(1998). A search for common ground: Value preferences of lay and religious Teachers in Roman catholic secondary school. Journal of catholic Education, 2(1). Retrived from http:// digitalcommons.lmu.edu/ce/voll2/iss 1/6 on 23.5.14.

[4] Moran, J.R.Frans, D. and Gibson,P.A. (1995). A comparison of beginning MSW and MBA students on their aptitudes for human service management. Journal of Social Work Education. Vol 31(1).pp, 95-105.

[5] Passakos,C. (1996). Twenty Five Years: Stability or change in Personal Values. Department of Education. University of Athens. Greece.

[6] Pastonjee,D.M., Akhtar, S.S. and Chowdry, T. (1967). A study of occupational values of male and female students. Indian Psychological Review.Vol4.pp.44-50. 
[7] Poduval,P.R.(1987). Value orientation of the MBA students, Paper presented at the U.G.C sponsored national level workshop on value orientation in management studies, Madurai.

[8] Reddy, K.M. and Parameswaran, E.G. (1966). Some Factors Influencing the Value Patterns of College Students. Research Bulletin. Vol. 2(2). pp.7-14.

[9] Segal,U.A. (1993). Cross cultural values: Social Work Students and Personality. International Social Work. vol. 36(1). Pp.61-73.

[10] Venkataiah, N.(2005). Value Education.APH Publishing Corporation, New Delhi. 